Review

\title{
Green Tea as an Agricultural Based Health Promoting Food: The Past Five to Ten Years
}

\section{Qin-Yin Shi and Vicki Schlegel *}

Department of Food Science and Technology, 143 Filley Hall, University of Nebraska Lincoln, Lincoln, NE 68583-0919, USA; E-Mail: qinyinshi@gmail.com

* Author to whom correspondence should be addressed; E-Mail: vschlegel3@unl.edu; Tel.: +1-402-416-0294.

Received: 5 September 2012; in revised form: 16 November 2012 / Accepted: 20 November 2012 / Published: 5 December 2012

\begin{abstract}
The consumption of tea originated in ancient China over 4000 years ago and is currently the second most popular beverage in the world after water. Tea is an aromatic beverage prepared by pouring hot water over cured leaves of the Camellia sinensis plant. The link between tea intake, most notably green tea, and health has resulted in intense research on the components responsible for preventing the onset of several chronic diseases, including atherosclerosis, cancer, obesity and diabetes. In particular, the high levels of chemically diverse phenols (e.g., phenolic acids, flavonoids) present in tea exhibit potent protective properties against many of these diseases. Although health related research on green tea and its predominant phenol (catechins) has been on-going for decades, major advances have occurred in the last 5-10 years. Therefore, this review focuses on seminal studies reported primarily within the last five years but not extending past ten years on the link between health and green tea with an emphasis on the catechins.
\end{abstract}

Keywords: green tea; phenols; flavonoids; oxidative stress; inflammation; health; catechins

\section{Introduction}

Tea originated in China over 4000 years ago and has since been a popular luxury commodity by the Asian population valued for its taste, aroma, medicinal applications, and cultural history [1]. The golden age of tea occurred during the Tang Dynasty (A.D. 618-906) as cultivation and trading routes expanded outside of China. The tea rules and ceremony developed by $\mathrm{Lu} \mathrm{Yu} \mathrm{(733-804)} \mathrm{as} \mathrm{described} \mathrm{in}$ 
Cha Chang or The Classic of Tea led to the earliest treatise on tea. Steaming of the leaves became the normal custom along with specific guidelines for processing the leaves and brewing the beverage. $\mathrm{Lu}$ Yu's work transformed the process into an art form and set the standard for tea cultivation/production in China. This ceremony eventually became the model that would emerge in Japan $[2,3]$. Tea arrived in Japan and Korea during the 6th century resulting in another highly sustainable market. Tea was subsequently introduced to Indonesia and India and then followed the trade routes into Europe $(\sim 1610)$, most notably Holland and England. At this point in world history, tea was considered such a high valued commodity that it was used for currency and international trade [2,3]. Tea is now cultivated in more than sixty countries with Asia (China, India, Japan, Sri Lanka, and Taiwan) producing more than $91 \%$ of the total amount annually (Table 1) [4]. While fermentation has aided in the ease of exporting tea and is a principal factor for the West's preference for black tea, green tea, or unfermented tea, is preferred in the East. However, tea drinking in North America and the Middle East of any kind is still comparatively low relative to China, Japan, and other European countries.

Table 1. Average annual tea production quantities by country (2005 to 2010).

\begin{tabular}{cc}
\hline Country & Quantities (tons) \\
\hline China & $1,217,039$ \\
India & 963,313 \\
Kenya & 344,596 \\
Sri Lanka & 304,036 \\
Turkey & 209,535 \\
Viet Nam & 167,531 \\
Indonesia & 154,328 \\
Iran & 108,751 \\
Japan & 92,233 \\
Argentina & 76,071 \\
Thailand & 59,203 \\
Bangladesh & 58,763 \\
Malawi & 46,155 \\
Uganda & 41,543 \\
United Republic of Tanzania & 31,850 \\
\hline
\end{tabular}

Data from FAO database (http://faostat3.fao.org/home/index.html [5]).

Green tea (GT) is made from the leaf of Camellia sinensis and is typically cultivated in hot humid climates [4]. Harvesting of high quality GT can simply be described as "two leaves and a bud" plucked from every new shoot. The process of GT production (Figure 1) preserves many compounds that have been linked to multiple human health properties making GT stand out from fermented black and semi-fermented oolong tea. As such, GT and its extracts have been used to enrich energy drinks, juices, vitamins, and other food systems. Of the health benefiting agents present in GT, the catechins have received major research focus [6,7]. Therefore, instead of attempting to summarize the wealth of literature published in this area, seminal studies reported primarily from the last five years but not extending past ten years will be reviewed with an emphasis on the GT catechins. 
Figure 1. Tea production and its influence on the final polyphenols content (adapted from Cabrera et al. [8]).

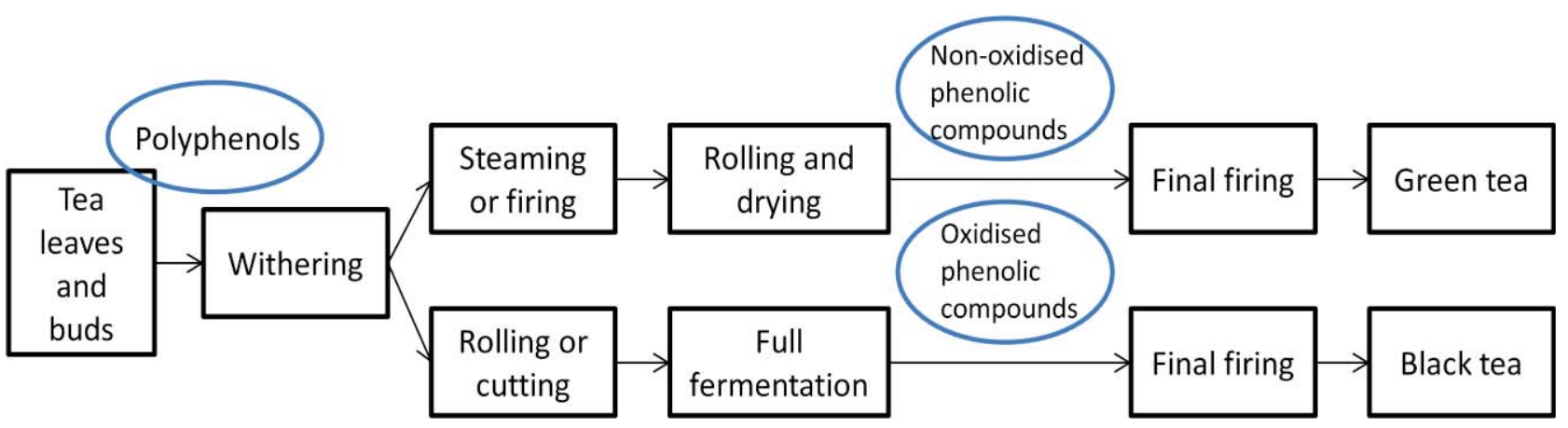

\section{Composition of Green Tea}

Green tea is a rich source of health promoting components (nutraceuticals or bioactives) largely due to its high levels of chemically diverse phenolic compounds, which account for $\sim 30 \%$ and $50 \%$ of the GT leaf and beverage on a dry weight basis, respectively (Figure 2).

Figure 2. Principal components of green tea leaf and green tea beverages (adapted from Balentine et al. [9]).

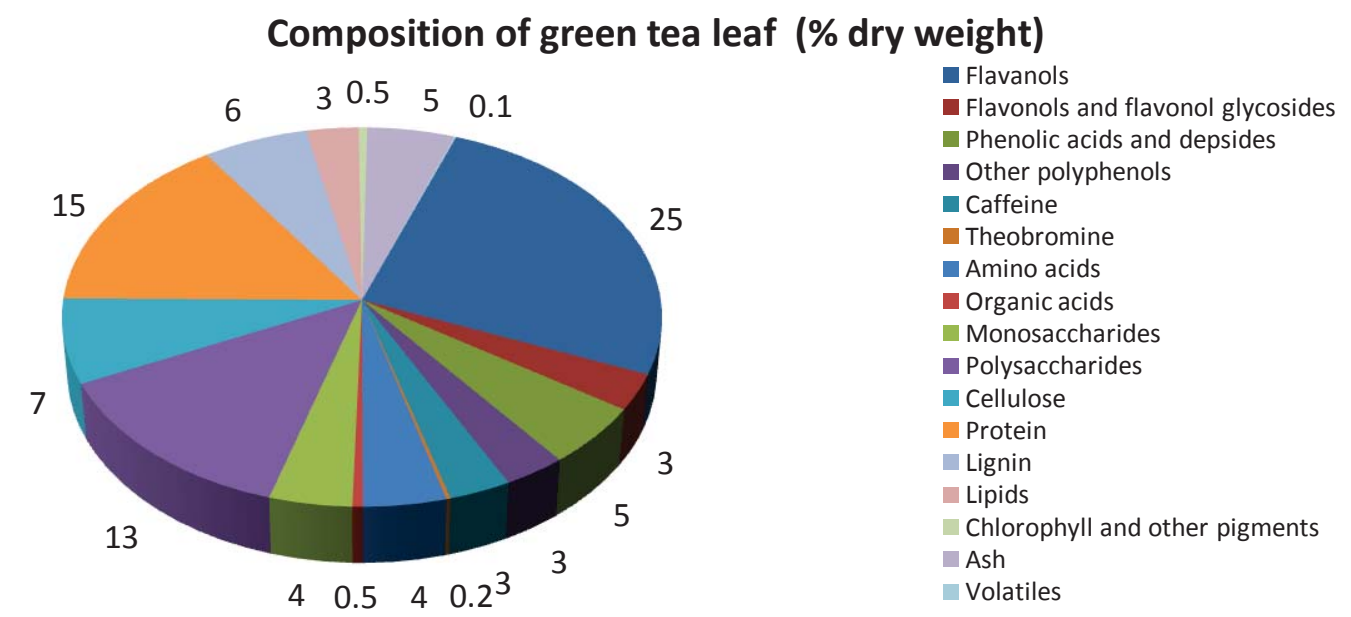

Composition of green tea beverage (\% wt/wt solids)

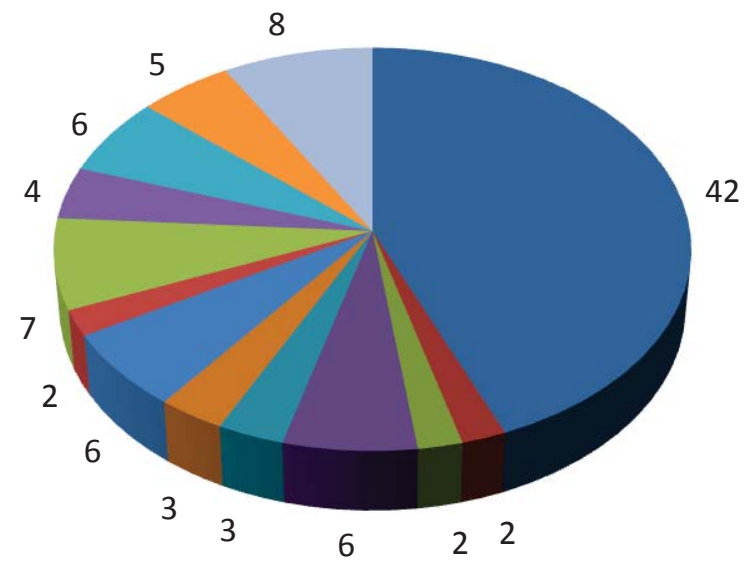

- Catechins

- Simple polyphenols

- Flavonols

- Other polyphenols

- Theanine

- Amino acids

- Peptides/protein

- Organic acids

- Sugars

- Other carbohydrates

- Caffeine

Potassium

- Other minerals/ash 
Flavan-3-ols are the major class of GT flavonoids with the catechins being the predominant form [9], including (-)-epicatechin (EC), (-)-epicatechin gallate (ECG), (-)-epigallocatechin (EGC) and (-)-epigallocatechin gallate (EGCG) (Figure 3). Among these compounds, EGCG represents $\sim 59 \%$ of the total catechins [8]. Green tea also contains the phenolic acids, gallic acid, chlorogenic acid and caffeic acid, and the flavonols, kaempferol, myricetin, quercetin and their conjugates (Figure 2). Other flavonoids that account for a very small fraction of the tea have more recently been identified and include 19 O-glycosylated flavonols, 7 C-glycosylated flavones, 28 acylated glycosylated flavonols and 3 flavonols [10]. While not the focus of this review, it must be noted that the fat soluble compounds present in GT, such as vitamin E and the carotenoids ( $2 \%$ dry weight) may work with the phenols to enhance health benefits [8] albeit limited studies have been reported on possible synergistic effects. Additionally, GT contains linoleic and linolenic acids (7\% dry weight) [9], which are only detected at trace levels after infusion as these compounds are involved in synthesizing the essential oils that contribute to the "green odor" [11]. Monosaccharide and water-soluble polysaccharides comprise nearly $20 \%$ of the GT leaf and are also compounds of interest due to their links to health [9]. Lastly, polysaccharide conjugates have been isolated but their structures vary depending on the origin of the tea $[12,13]$.

Figure 3. Structure of major green tea flavonoids.

Flavanols: catechins

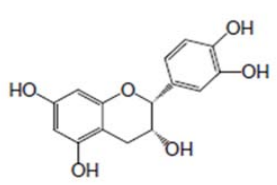

(-)-epicatechin

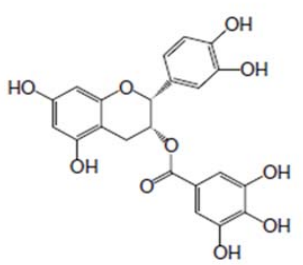

(-)-epicatechin gallate

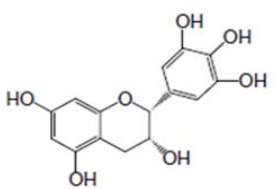

(-)-epigallocatechin

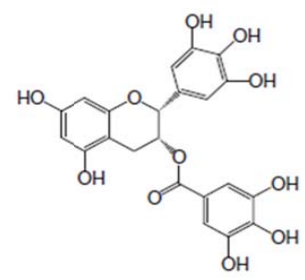

(-)-epigallocatechin galla

Phenolic acids:<smiles>O=C(O)c1cc(O)c(O)c(O)c1</smiles>

gallic acid<smiles>O=C(/C=C/c1ccc(O)c(O)c1)OC1CC(O)(C(=O)O)CC(O)C1O</smiles>

chlorogenic acid<smiles>O=C(O)/C=C/c1ccc(O)c(O)c1</smiles>

caffeic acid

Flavonols:<smiles>O=c1c(O)c(-c2ccc(O)cc2)oc2cc(O)cc(O)c12</smiles>

kaempferol<smiles>O=c1c(O)c(-c2cc(O)c(O)c(O)c2)oc2cc(O)cc(O)c12</smiles>

myricetin<smiles></smiles>

quercetin 


\section{Oxidative Stress}

Reactive oxygen species (ROS), such as the hydroxyl radical $(\mathrm{OH})$, superoxide $\left(\mathrm{O}_{2}{ }^{-}\right)$and hydrogen peroxide $\left(\mathrm{H}_{2} \mathrm{O}_{2}\right)$, maintain cellular homeostasis by acting as cell signaling agents or by regulating gene expression [14,15]. If left unchecked however ROS imbalances can cause cellular oxidative stress that can lead to chronic conditions and diseases, e.g., cancer, cardiovascular diseases and neurodegenerative diseases. Reports have shown that GT and its predominant phenols (in isolation) prevent or remediate oxidative stress via multiple mechanisms. A recent study by Schroeder et al. [16] showed that the most abundant GT catechin (EGCG) protected the neuron by lowering levels of mitochondrial free radicals and preventing apoptosis induced by oxidative stress. Guo et al. [17] demonstrated that GT catechins fed to a 6-OHDA rat model presented with reduced levels of inducible nitric oxide (NO) synthase and protein-bound 3-nitro-tyrosine. GT catechins also prevented ROS and NO generation, lipid peroxidation and increased nitrite/nitrate ratio in a dose dependent manner. GT polyphenols also play a role in reducing cellular levels of ROS generating redox-active metals. Quesada et al. [18] determined that EGCG binds to zinc cations with high affinity thereby reducing the accumulation of zinc in a human liver hepatocellular carcinoma (HepG2) cell model. Another study reported by Wei and Meng [19] showed that EGCG reversed lead-induced oxidative damage in ventricular myocytes isolated from rat hearts and reduced $\mathrm{OH}, \mathrm{O}_{2}{ }^{-}$, and $\mathrm{H}_{2} \mathrm{O}_{2}$ levels.

By acting as a pro-oxidant, GT has often been linked to the apoptotic induction of tumor cells [20]. Oxidative stress induced by GT polyphenols may also trigger endogenous antioxidant systems in normal tissues. Maeta et al. [21] showed that $0.1 \%$ GT extract or $0.05 \%(1.1 \mathrm{mM})$ EGCG produced $\mathrm{H}_{2} \mathrm{O}_{2}$ in yeast models grown in weak alkaline medium. Nuclear localization of oxidative-stress-responsive transcription factors (Yap1 and Msn2 in S. cerevisiae, and Pap1 in S. pombe) were subsequently activated. Elbling et al. [22] reported the autoxidation of EGCG resulted in low-doses of $\mathrm{H}_{2} \mathrm{O}_{2}$, reduced DNA damage and cytotoxicity in keratinocyte-derived HaCat cell. Additionally, these low levels of $\mathrm{H}_{2} \mathrm{O}_{2}$ initiated the up-regulation of antioxidant enzymes and lowered ROS levels. The antioxidant and pro-oxidant effects of GT polyphenols may be linked to other health benefits discussed in subsequent sections. A summary of this information and associated references are provided in Table 2 .

\section{Inflammation}

Inflammation is the body's way of dealing with localized tissue damage/infection and is thus critical to our survival. Yet, low grade but continued stimulation of the inflammatory response can lead to chronic inflammation, which can then progress to coronary heart diseases, Alzheimer's disease, type 2 diabetes, muscle degeneration, and cancer [23-25]. Many reports have shown the anti-inflammatory properties of GT but the mechanisms eliciting the response vary between the studies.

Neutrophils are triggered at a specific site in the body by infections, tissue necrosis, necrotic cells, foreign bodies-dirt, and immune signals, including those of chronic inflammation thereby contributing to the inflammatory cycle. Dona et al. [26] reported that EGCG not only inhibited neutrophil elastase in an in vitro model but also down-modulated ROS activity, caspase-3 activity, DNA fragmentation, and the ability of neutrophiles to migrate towards a chemotactic stimulus. The in vivo part of this study showed that EGCG inhibited neutrophil recruitment, inflammation-driven angiogenesis, and 
pulmonary fibrosis. Yet another in vivo study completed by Shen et al. [27] demonstrated that fibrosis in female rats caused by chronic inflammation was significantly reduced when treated with GT catechins.

Table 2. Recent studies on green tea and oxidative stress.

\begin{tabular}{|c|c|c|c|c|}
\hline References & Model & Treatment & Dosage & Main outcomes \\
\hline $\begin{array}{c}\text { Schroeder et al. } \\
{[16]}\end{array}$ & $\begin{array}{l}\text { Rat cerebellar granule } \\
\text { neurons cultures }\end{array}$ & EGCG & $\begin{array}{c}5,10 \text {, or } \\
20 \mu \mathrm{M}\end{array}$ & $\begin{array}{l}90 \%-95 \% \text { of }{ }^{3} \mathrm{H}-\mathrm{EGCG} \\
\text { accumulated in mitochondria. } \\
\text { EGCG treatments resulted in } \\
\text { reduced levels of free radicals and } \\
\text { protected neuron from apoptosis } \\
\text { induced by oxidative stress. }\end{array}$ \\
\hline $\begin{array}{l}\text { Guo et al. } \\
\text { [17] }\end{array}$ & $\begin{array}{c}\text { 6-hydroxydopamine } \\
\text { (6-OHDA)-treated rat } \\
\text { model of Parkinson's } \\
\text { Disease }\end{array}$ & $\begin{array}{c}\text { GTP }(98 \% \\
\text { purity) } \\
\text { containing } 50 \% \\
\text { EGCG, } 22 \% \\
\text { ECG, } 18 \% \text { EGC } \\
\text { and } 10 \% \text { EC }\end{array}$ & $\begin{array}{c}150,450 \\
\mathrm{mg} / \mathrm{kg} / \\
\text { day-fed }\end{array}$ & $\begin{array}{l}\text { GTP treatment dose-dependently } \\
\text { decreased ROS and NO level, } \\
\text { lipid peroxidation, nitrite/nitrate } \\
\text { ratio, and expression of inducible } \\
\text { nitric oxide synthase and } \\
\text { protein-bound 3-nitro-tyrosine. }\end{array}$ \\
\hline
\end{tabular}

\section{Quesada et al.}

[18]

Human HepG2 cells

EGCG

$10 \mu \mathrm{M}$

EGCG binded to zinc cations with high affinity and thus reduced the accumulation of zinc.

\begin{tabular}{|c|c|c|c|c|}
\hline $\begin{array}{l}\text { Wei \& Meng } \\
\quad[19]\end{array}$ & $\begin{array}{l}\text { Myocytes from the } \\
\text { hearts of adult rats }\end{array}$ & EGCG & $0-60 \mu \mathrm{g} / \mathrm{mL}$ & $\begin{array}{l}\text { Formation of } \mathrm{OH}^{-}, \mathrm{O}_{2}^{-} \text {, and } \mathrm{H}_{2} \mathrm{O}_{2} \\
\text { was decreased significantly as } \\
\text { EGCG concentration increased } \\
\text { compared to lead treated group. }\end{array}$ \\
\hline $\begin{array}{l}\text { Maeta et al. } \\
\quad[21]\end{array}$ & $\begin{array}{l}\text { Budding yeast } S \text {. } \\
\text { cerevisiae and fission } \\
\text { yeast } S \text {. pombe }\end{array}$ & EGCG and GTE & $\begin{array}{c}0.05 \% \\
\text { EGCG } \\
0.1 \% \text { GTE }\end{array}$ & $\begin{array}{l}\mathrm{H}_{2} \mathrm{O}_{2} \text { produced by EGCG and } \\
\text { GTE induced the expression of } \\
\text { nuclear localization of } \\
\text { oxidative-stress-responsive } \\
\text { transcription factors (Yap1 and } \\
\text { Msn2 in } S \text {. cerevisiae, and Pap1 in } \\
\text { S. pombe). }\end{array}$ \\
\hline $\begin{array}{c}\text { Elbling et al. } \\
\text { [22] }\end{array}$ & Human keratinocytes & EGCG & $0-100 \mu \mathrm{M}$ & $\begin{array}{l}\text { Low-dose } \mathrm{H}_{2} \mathrm{O}_{2} \text { and EGCG } \\
\text { treatment enhanced the clearance } \\
\text { of ROS and reduced DNA } \\
\text { damage and cytotoxicity in } \\
\text { keratinocyte-derived HaCat cell. }\end{array}$ \\
\hline
\end{tabular}

EGCG: (-)-epigallocatechin gallate; ECG: (-)-epicatechin gallate; EGC: (-)-epigallocatechin; EC: (-)-epicatechin; GTP: green tea polyphenols; ROS: reactive oxygen species; NO: nitric oxide; GTE: green tea extract; HaCAT: human keratinocyte line. 
Regulatory $\mathrm{T}$ cells (T-reg) are essential in maintaining immune functions by targeting sites of sustained inflammation [28]. Recent in vitro and in vivo studies showed that EGCG $(2-50 \mu \mathrm{M})$ induced T-reg via the up-regulation of Foxp3, i.e., a transcription factor regulated by DNA methylation [29]. The effect of EGCG on Foxp3 gene expression was similar to that of DNA methyltransferase inhibitors. EGCG also inhibited nuclear factor-kappa B (NF- $\mathrm{B})$-mediated inflammatory responses in mice models via the $\mathrm{Nrf} 2$ antioxidant signaling pathway by increasing systemic T-reg cell activity [30]. Wu et al. [31] investigated the ability of EGCG to suppress proliferation of T-reg in the spleen of C57BL mice. The results indicated that 2.5 to $10 \mu \mathrm{M}$ EGCG inhibited T-reg proliferation but did not induce apoptosis or increase oxidative stress. These researchers identified that the EGCG modulated pathway was related to IL-2/IL-2 receptor signaling.

Other mechanisms involving the inhibition of immune related cell signaling in response to GT-polyphenols have been reported. Ranjith-Kumar et al. [32] showed that GT-EGCG can bind to the retinoic acid inducible gene I (RIG-I) and thus interfere with interferon signaling response in mammalian HEK293T cells. Moreover, this polyphenol was able to suppress ATPase activity of recombinant RIG-I without competing with RIG-I and RNA or ATP. Analysis of the structure-activity relationship of commercially available analogs revealed that RIG-I inhibitors included epimers gallocatechin gallate and theaflavin 3,3' digallate. EGCG was also shown to down regulate gene expression related to macrophage migration. Using human keratinocytes, Noh and Park [33] reported down regulation of the dexamethasone-induced macrophage migration inhibitory factor (MIF) in the presence of EGCG and the expression of MIF-induced cytokines and chemokines, such as interleukin (IL)-6, IL-18, transforming growth factor- $\beta$, CCL17, CCL22 and CXCL10, were subsequently inhibited. Ripley et al. [34] reported that EGCG up-regulated STAT5 transcription factor and induced the suppressor of cytokine signaling 1 gene through the superoxide pathway. These studies are itemized in Table 3.

\section{Cardiovascular Health}

Studies have also increased on GT intake and the promotion of cardiovascular health [35,36]. Qin et al. [37] showed that GT polyphenols can alter the mRNA expression of the cardiac insulin signaling pathway, regulate cardiac mRNA expression of cardiac lipid metabolism, and regulate the inflammation-related gene expression in insulin resistant rats fed a high-fructose diet. These results indicate the potential ability of GT to reduce the risk of coronary artery disease. Another study by Lorenz et al. [38] compared stimulus NO production and vasodilation in response to GT and black tea exposure. In the presence of the GT catechins, eNOS activity and vasorelaxation were induced by activating and phosphorylating the signaling kinases in endothelial cells. Similar results were obtained with black tea indicating that the theaflavins and thearubigins may be the responsible components. El Bedoui et al. [39] also showed that EGCG inhibited matrix metalloproteinase-2 activity and thus prevented vascular smooth muscle cell invasion. 
Table 3. Recent studies on green tea and inflammation.

\begin{tabular}{|c|c|c|c|c|}
\hline References & Model & Treatment & Dosage & Main Outcomes \\
\hline $\begin{array}{l}\text { Dona et al. } \\
\quad[26]\end{array}$ & $\begin{array}{l}\text { Neutrophils and } \\
\text { C57 black mice }\end{array}$ & EG CG & $1-100 \mu \mathrm{M}$ & $\begin{array}{l}\text { EGCG down-modulated ROS activity, } \\
\text { and inhibited apoptosis and chemotaxis } \\
\text { in vitro model. EGCG also inhibited } \\
\text { neutrophil recruitment, angiogenesis and } \\
\text { pulmonary fibrosis. }\end{array}$ \\
\hline Shen et al. [27] & $\begin{array}{l}\text { 3-month-old } \\
\text { female rats }\end{array}$ & $\begin{array}{l}\text { GTP }(98.5 \% \\
\text { purity })\end{array}$ & $\begin{array}{l}0.5 \% \text { in } \\
\text { water }\end{array}$ & $\begin{array}{l}\text { The development of fibrosis in vessels } \\
\text { and myocardium in rat decreased } \\
\text { significantly with supplementation } \\
\text { via down-regulation of TNF- } \alpha \\
\text { mRNA expression. }\end{array}$ \\
\hline Wong et al. [29] & $\begin{array}{l}\text { Human Jurkat } \\
\text { leukemic } \mathrm{CD}^{4+} \mathrm{T} \\
\text { cell line and } \\
\text { eight-week old } \\
\text { Balb/c male mice }\end{array}$ & $\begin{array}{l}\text { EGCG } \\
\text { GT } \\
\text { beverage }\end{array}$ & $\begin{array}{l}2,10,50 \\
\mu \mathrm{M} \\
2 \%, \mathrm{w} / \mathrm{v}\end{array}$ & $\begin{array}{l}\text { EGCG induced expression of Foxp } 3 \text { and } \\
\text { increased T-reg frequencies and } \\
\text { numbers both in vitro and in vivo. }\end{array}$ \\
\hline Tsai et al. [30] & $\begin{array}{l}12 \text {-weeks-old } \\
\text { female NZB/W } \\
\text { F1 mice }\end{array}$ & EGCG & $\begin{array}{c}120 \mathrm{mg} / \mathrm{kg} \\
\text { body weight }\end{array}$ & $\begin{array}{l}\text { T-reg activity increased in EGCG } \\
\text { treated mice. }\end{array}$ \\
\hline Wu et al. [31] & $\begin{array}{l}\text { C57BL mice } \\
\text { spleen cells }\end{array}$ & EGCG & $2.5-10 \mu \mathrm{M}$ & $\begin{array}{l}\text { EGCG targeted the pathway which is } \\
\text { related to IL-2/IL-2 receptor signaling } \\
\text { and inhibited T cell proliferation. }\end{array}$ \\
\hline $\begin{array}{l}\text { Ranjith-Kumar } \\
\quad \text { et al. [32] }\end{array}$ & $\begin{array}{c}\text { Human } \\
\text { HEK293T cells }\end{array}$ & EGCG & $0-10 \mu \mathrm{M}$ & $\begin{array}{l}\text { EGCG inhibited RIG-I by binding to } \\
\text { RIG-I and suppressing ATPase activity } \\
\text { of recombinant RIG-I. }\end{array}$ \\
\hline $\begin{array}{c}\text { Noh and Park } \\
\text { [33] }\end{array}$ & $\begin{array}{c}\text { Human } \\
\text { keratinocytes }\end{array}$ & EGCG & $100 \mu \mathrm{mol} / \mathrm{L}$ & $\begin{array}{l}\text { EGCG down regulated MIF mRNA } \\
\text { expression and MIF induced cytokines } \\
\text { and chemokines. }\end{array}$ \\
\hline Ripley et al. [34] & $\begin{array}{l}\text { Monocytes of } \\
\text { human PBMCs } \\
\text { and SOC1- } \\
\text { deficient } \\
\text { C57BL/6 mice }\end{array}$ & $\begin{array}{l}\text { GTE and } \\
\text { EGCG }\end{array}$ & $0-200 \mu \mathrm{M}$ & $\begin{array}{l}\text { EGCG inhibited cytokine signaling } \\
1 \text { gene expression via inducing the } \\
\text { SOC1 expression and un-regulating } \\
\text { STAT5 transcription factor. }\end{array}$ \\
\hline
\end{tabular}

EGCG: (-)-epigallocatechin gallate; GTP: green tea polyphenols; TNF- $\alpha$ : tumor necrosis factor alpha; GT: green tea; IL-2: interleukin 2; RIG-I: retinoid-inducible gene 1; MIF: migration inhibitory factor; PBMCs: peripheral blood mononuclear cells, GTE: green tea extract. 
Other studies have shown that GT polyphenols may function by modulating cholesterol metabolism. Bursill and Roach [40] reported decreased cholesterol synthesis in HepG2 cells when incubated with $50 \mu \mathrm{M}$ of GT-EGCG. However, cholesterol synthesis increased significantly using $200 \mu \mathrm{M}$ of GT-EGCG while cellular cholesterol remained at a low level. In the latter case, 30\% more cholesterol was detected in medium indicating that higher EGCG concentrations promoted the efflux of cholesterol. Although the researchers used other GT catechins, GCG was the only catechin capable of up regulating low-density lipoprotein (LDL) receptor activity [40]. Up-regulation of LDL receptor also occurred in GT-polyphenolic fed cholesterol-fed rabbits [41]. Six experimental rabbits fed a $0.25 \%$ (w/w) cholesterol diet for two weeks followed by catechin enriched diets supplemented of $0,0.5,1$ or $2 \%(\mathrm{w} / \mathrm{w})$ for four weeks showed up-regulation of LDL receptor activity and a $60 \%$ reduction in plasma cholesterol ( $80 \%$ in LDL cholesterol).

Multiple human clinical studies have been completed to determine the anti-arthrosclerosis benefits of GT consumption. In one study [42], 14 healthy individuals at an average age of 30 years were separated into three groups. Each group consumed one of $450 \mathrm{ml}$ of $6 \mathrm{~g}$ GT (brewed Lipton tea), $250 \mathrm{mg}$ caffeine (amount contained in GT) or water. Flow-mediated dilatation (FMD) of the brachial artery was then measured at 30, 90, 120 min intervals. FMD significantly increased in the GT group but were similar in both the caffeine and water control groups suggesting possible benefits of GT on coronary endothelial function. Zheng et al. [43] identified and quantified the possible effects of a GT beverage versus a GT extract on human cholesterol profiles by performing a meta-analysis of 14 randomized trials reported in the literature. The researchers concluded that GT consumption had no significant effect on high density lipoprotein cholesterol in fasting serum but significantly reduced total cholesterol levels by $7.20 \mathrm{mg} / \mathrm{dL}$ and significantly decreased the LDL-cholesterol concentration by $2.19 \mathrm{mg} / \mathrm{dL}$. In reviews by Deka and Vita [35] and Del Rio et al. [36], other epidemiological data providing evidence for and against GT and cardiovascular health connection are summarized.

\section{Obesity and Diabetes}

Metabolic syndrome is a multifaceted condition characterized by elevated waist circumference, dysglycemia, elevated blood pressure, decreased serum high-density lipoprotein-associated cholesterol, and increased serum triglycerides, i.e., risk factors for diabetes and cardiovascular disease. As metabolic cases are increasing at an unprecedented rate in the US and throughout other western countries, there is considerable interest in the potential benefit of tea consumption for prevention of metabolic syndrome [44]. Numerous in vitro studies and animal models have shown beneficial effects of GT catechins on several of these risk factors, including reduced body fat, improved glucose tolerance and maintenance of a healthy cardiovascular system. As studies specific to GT and cardiovascular health have been discussed in the previous section, select obesity and diabetes related research will be presented in this section.

Several studies using animal models investigated the possible relationships between GT phenols and the development of obesity and other related disease risk factors. Bose et al. [45] reported that three month old obese mice fed a high fat (HF) diet but supplemented with EGCG not only attenuated the development of metabolic syndrome but also reversed the symptoms. Body weight, body fat, blood glucose, plasma insulin, plasma cholesterol, inflammatory markers and liver fat were all significantly 
lower in 16 weeks for the mice fed the HF diet + EGCG compared to the control. After receiving a $3.2 \mathrm{~g} / \mathrm{kg}$ EGCG supplemented diet, the visceral fat weight in the mice decreased $36 \%$ in nine weeks and blood glucose level decreased $22 \%$ in four weeks [45]. Sae-tan [46] showed that C57bl/6J mice fed a HF diet that included EGCG $(0.32 \%$ dietary) for 16 weeks resulted in increased gene expression (1.4- to 1.9-fold) of several proteins involved in mitochondrial fatty acid oxidation, including nuclear respiratory factor 1 , medium chain acyl coA decarboxylase, uncoupling protein 3 , and peroxisome proliferator responsive element $\alpha$. In addition, increased lipids in the fecal material of the mice were reported. Another proposed mechanism included modulation of fat lost via an EGCG link. Lee et al. [47] tested the hypothesis that EGCG promotes triacylglycerol hydrolysis by increasing gene expression of hormone sensitive lipase. In this study, lipid accumulation in 3T3-L1 adipocytes decreased significantly after a $24 \mathrm{~h}$ treatment with $10 \mu \mathrm{M}$ EGCG while cell viability was retained. Richard et al. [48], used male-deficient (ob/ob) mice and their lean counterparts (mice C57BL/6J mice) to investigate whether regular decaffeinated green tea intake affected body weight and lipid profiles. GT consumption resulted in significantly lower weight gain in the obese mice and associated cholesterolemia, triglyceridemia, and adiponectin concentrations but did not adversely affect the lean model.

Cao et al. [49] determined the possible molecular mechanistic connection between GT catechins using a high-fructose fed mice model. This study showed that 1-2 g of GT extracts influenced gene expression of several important regulators of glucose intake and insulin signal pathways. In a similar study, Hininger-Favier et al. [50] demonstrated the effects of GT extracts on insulin sensitivity using Wistar rats fed a high-fructose diet (FD) without or with 1 or $2 \mathrm{~g}$ of GT supplements for six weeks. The FD fed rats developed insulin resistance while rats fed GT supplements did not. Additionally, the rats fed the GT supplement presented with decreased levels of plasma lipid peroxidation, sulfhydryl group oxidation, and DNA oxidative damage. A recent study by Ma et al. [51] revealed tyrosine phosphatase (purified from E. coli) was inhibited in response to a GT extract. As a down regulator of both the insulin and leptin signaling pathways, inhibitors of tyrosine phosphatase are considered promising approaches to treat diabetes and obesity.

Other studies using human subjects of Asian descent have shown the benefits of GT intake in terms of reducing risk factors for obesity and diabetes [52-54]. In particular, the Ohsaki study [54], which followed 40,530 Japanese adults (aged from 40 to 79) for 11 years, revealed a strong inverse association between GT consumption and cardiovascular disease mortality. Recently, researchers at the Oklahoma State University compared body weight, lipids and lipid peroxidation in 35 obese subjects provided either a product with or without a GT extractable [55]. These results supported the Ohsaki study again positively correlating GT intake with decreased body weight, body mass index and biomarkers for lipid peroxidation (malondialdehyde and hydroxynonenals).

\section{Cancer}

According to Khan and Mukhtar [56], 765 reports have been published showing the potential of GT polyphenols as cancer chemoprevention agents. Therefore, only a sample of those studies is provided in this section (also refer to Table 4). For example, Ohga et al. [57] studied GT-EGCG as a therapeutic treatment against several different cancer cell lines. While EGCG had no adverse effect on 
normal endothelial cells, it did exert anti-angiogenic properties by selectively suppressing the migration of tumor-associated endothelial cells and endothelial progenitor cells. Kato et al. [58] studied the response of the RECK gene, a novel tumor suppressor gene, in oral squamous cell carcinoma cell lines (oral cancer cell) treated with EGCG. The hypermethylation status of the RECK gene was partially reversed by EGCG whereas the gene expression level of RECK mRNA was significantly enhanced.

A recent in vitro study showed that GT-EGCG inhibited the growth of advanced prostate cancer by competitively binding to the androgen receptor (AR) and interrupting the gene expression regulated by AR [59]. EGCG acted at multiple levels including inhibiting interdomain $N-C$ termini interaction, repressing the prostate cancer related mutant T877A and eventually inhibiting cancer cell growth. Lee et al. [60] obtained similar results using a prostate cancer cell line in response to GT catechins. The researchers proposed that catechins modulated AR acetylation was modulated in the presence of GT catechins thereby inhibiting the translocation of the AR protein to the nucleus. The activity was comparable to that exhibited by anti-histone acetyltransferase.

Although the cited studies were conducted with experimental cell models, many others have included tissues collected from human clinic trials (animal and human). By using six tumor related genes in 106 gastric cancer patients, Yuasa et al. [61] showed that methylation of homeobox transcription factor and bone morphogenetic protein 2 were inversely correlated with GT intake. Thangapazham et al. [62] used both a cell system and an animal model to study the inhibitory effect of GT polyphenols, with an emphasis on EGCG, on human breast cancer cells. The phenol treatments resulted in down regulating cancer related genes and inhibiting cancer cell proliferation. Moreover, GT polyphenols and EGCG induced apoptosis in cancer cells of an athymic nude mice model. In another animal study, Henning et al. [63] xenotransplanted human prostate tumor into severe combined immunodeficiency (SCID) mice and then replaced water with brewed GT for 13 weeks. Tumor volume, oxidized DNA and protein damage in tumor tissue were all significantly reduced with GT consumption. Decreased expression of hypoxia-inducible factor 1-alpha, vascular endothelial growth factor and tumor 5-cytosine DNA methyltransferase 1 mRNA also occurred [63].

Other studies have focused on the general effect of GT beverage consumption on cancer prevention. Bettuzzi et al. [64] conducted a one-year double blind clinical trial on men with high-grade prostate intraepithelial neoplasia. Among the volunteers who were given catechins, only one tumor was diagnosed whereas nine cancers were detected among the placebo group. The catechin treated volunteers received significantly better scores on the international prostate symptom score and exhibited no significant side or adverse effects. However, in the 11 years of the previously discussed Ohsaki study, GT consumption did not correlate with decreased cancer related mortality [54]. Although research remains limited in human subjects, the combined (in vitro and in vivo) literature show the potential of GT to protect against oral, prostate, lung, colorectal cancer, and other target tissues. Such studies have been presented in several recently published reviews [65-67]. 
Table 4. Recent studies on green tea and cancer.

\begin{tabular}{|c|c|c|c|c|}
\hline References & Model & Treatment & Dosage & Main outcomes \\
\hline Ohga et al. [57] & $\begin{array}{l}\text { Human cell lines } \\
\text { A375SM and } \\
\text { HSC3 }\end{array}$ & EGCG & $100 \mu \mathrm{M}$ & $\begin{array}{l}\text { EGCG selectively targeted } \\
\text { tumor-associated endothelial } \\
\text { cells and endothelial progenitor } \\
\text { cells, thereby suppressing their } \\
\text { migration. }\end{array}$ \\
\hline $\begin{array}{l}\text { Kato et al. } \\
\quad[58]\end{array}$ & $\begin{array}{l}\text { Human cell lines } \\
\text { HSC3, HSC4, } \\
\text { SCC9, SCC25 and } \\
\text { HeLa }\end{array}$ & EGCG & $5,10,20,50 \mu \mathrm{M}$ & $\begin{array}{l}\text { EGCG treatment partially } \\
\text { reversed the hypermethylation } \\
\text { status of the RECK gene. }\end{array}$ \\
\hline $\begin{array}{l}\text { Siddiqui et al. } \\
\text { [59] }\end{array}$ & $\begin{array}{l}\mathrm{LNCaP} \text { and } 22 \mathrm{R} v 1 \\
\text { cells }\end{array}$ & EGCG & $\begin{array}{c}0,10,20,40 \\
60 \mu \mathrm{M}\end{array}$ & $\begin{array}{l}\text { EGCG competitively binding to } \\
\text { AR and interrupting the gene } \\
\text { expression regulated by AR. }\end{array}$ \\
\hline Yuasa et al. [61] & $\begin{array}{l}\text { Tissue of gastric } \\
\text { cancer patients }\end{array}$ & Brewed GT & $0-10$ cups per day & $\begin{array}{l}\text { Methylation of CDX2 and } \\
\text { BMP-2 were inversely } \\
\text { correlated with GT intake }\end{array}$ \\
\hline $\begin{array}{c}\text { Thangapazham } \\
\text { et al. }[62]\end{array}$ & $\begin{array}{l}\text { MDA-MB-231 cell } \\
\text { line and athymic } \\
\text { nude mice model }\end{array}$ & $\begin{array}{c}\text { EGCG and } \\
\text { GTP }\end{array}$ & $0-200 \mu \mathrm{g} / \mathrm{ml}$ & $\begin{array}{l}\text { EGCG and GTP down regulated } \\
\text { cancer related gene expression } \\
\text { and inhibited proliferation of } \\
\text { cancer cell. }\end{array}$ \\
\hline $\begin{array}{c}\text { Henning et al. } \\
{[63]}\end{array}$ & Male SCID mice & Brewed GT & & $\begin{array}{l}\text { Tumor volume, oxidative DNA } \\
\text { and protein damage in tumor } \\
\text { tissue were all significantly } \\
\text { reduced with GT consumption. }\end{array}$ \\
\hline $\begin{array}{c}\text { Bettuzzi et al. } \\
\text { [64] }\end{array}$ & $\begin{array}{l}\text { Men with high- } \\
\text { grade prostate } \\
\text { intraepithelial } \\
\text { neoplasia }\end{array}$ & $\begin{array}{c}\text { GT } \\
\text { catechins }\end{array}$ & $600 \mathrm{mg} /$ day & $\begin{array}{l}\text { One tumor was diagnosed in } \\
\text { treatment group whereas nine } \\
\text { cancers were detected among } \\
\text { the placebo group. Treated } \\
\text { group received higher score of } \\
\text { international prostate symptom. }\end{array}$ \\
\hline $\begin{array}{c}\text { Kuriyama et al. } \\
{[54]}\end{array}$ & Japanese adults & Brewed GT & $\begin{array}{l}<1,1-2,3-4,>5 \\
\text { cups per day }\end{array}$ & $\begin{array}{l}\text { GT consumption did not } \\
\text { significantly associate with } \\
\text { cancer mortality. }\end{array}$ \\
\hline
\end{tabular}

EGCG: (-)-epigallocatechin gallate; AR: androgen receptor; GTP: green tea phenols; GT: green tea.

\section{Gastrointestinal Health}

The human gastrointestinal (GI) tract contains more microorganisms than any other surface of the human body with the large intestine alone containing approximately $10^{14}$ microorganisms [68]. 
Although remarkably constant within an individual over time, the microbiome can be perturbed by diseases or modulated by probiotic or prebiotic interventions [68-74]. Dietary polyphenols can also impact the GI microbiome by the time of absorption. Lee et al. [75] have provided extensive information on the gut microflora in response to GT extracts and their aromatic metabolites. The results showed that metabolites were produced by the bacteria after exposure to a GT polyphenol rich extract but their sensitivity towards polyphenols varied among species. The proliferation of "Good" bacteria (commensal anaerobes), which have been linked to benefits associated with host nutrition and health, were less affected by the extract but growth of pathogenic bacteria were significantly reduced. Su et al. [76] studied the effect of a commercial GT extract product containing 94\% EGCG on three pathogenic bacteria (Staph. Aureus and Strep. Pyogenes), E. coli, and three probiotic bacteria (L. acidophilus, B. animalis and L. casei). The growth of all three pathogens was inhibited by GT at significantly lower levels (minimum inhibition concentration (MIC) of $100 \mu \mathrm{g} / \mathrm{mL} \mathrm{GT}$ ) compared to the three probiotic bacteria ( $\mathrm{MIC}>800 \mu \mathrm{g} / \mathrm{mL}$ ). Moreover, a synergistic effect between the probiotics and GT product was reported resulting in reduced growth of the pathogenic bacteria. The GT MIC value for $E$. coli was comparable to that of the probiotic bacteria. These results are consistent with a later study demonstrating that a GT extract inhibited probiotic bacteria and E. coli indiscriminately [77]. Alternatively, Molan et al. [78] compared two types of GT with different mineral composition. Exposure to a Chinese GT only slightly increased the growth of L. rhamnosus but had no effect on B. breve. However, the selenium-containing GT positively influenced the growth of both organisms indicating that the selenium content in GT could be a major factor in promoting probiotic bacterial growth.

\section{Bioavailability}

Research on the bioavailability of GT polyphenols is essential in order to understand their health promoting mechanisms. However, such studies have typically used cell models under certain digestion conditions while animal and human clinical trials remain limited. Nonetheless, Green et al. [79] conducted an in vitro digestive recovery experiment with EC, EGC, EGCG and ECG by subjecting each to a digestion protocol that mimicked the gastric and small intestinal environment. The results showed poor recovery of the pure catechins $(<10 \%)$ after exposure to the digestion process. Conversely, a more recent study demonstrated that GT catechins are highly bioavailable [80]. In this study, plasma and urine samples were collected from ten healthy men before and after ingestion of $500 \mathrm{~mL}$ GT beverage containing $648 \mu \mathrm{mol}$ of flavan-3-ols over a $24 \mathrm{~h}$ period. A $\mathrm{C}_{\max }$ of $29 \sim 126 \mathrm{nM}$ occurred in the plasma at 1.6 2.3 $\mathrm{h}\left(\mathrm{T}_{\max }\right)$ post ingestion indicating that absorption occurred in the small intestine. Analysis of the urine samples showed $11.4 \%$ recovery of EGC and $28.5 \%$ of EC. The researchers also noted that accurate quantification of catechins bioavailability cannot be accessed solely by $\mathrm{C}_{\max }$ and $\mathrm{T}_{\max }$ values because flavan-3-ols metabolites rapidly circulate in the system. Roowi et al. [81] studied flavan-3-ols degradation in the large intestine by incubating GT-EC, EGC, and EGCG with human fecal samples. The results showed degradation of the flavan-3-ols at concentrations equivalent to $40 \%$ of the initial intake. A follow-up study completed by Calani et al. [82] identified GT flavan-3-ol metabolites in the urine of 20 volunteers. For the first time, 
six colonic metabolites were recovered supporting the important role of colonic microbiota in the digestion of GT flavan-3-ol. The mean bioavailability was approximately $62 \%$ after $48 \mathrm{~h}$.

Green tea polyphenols bioavailability can be enhanced with food additives or by ingestion through different forms. By combining a catechin extract with food additives (ascorbic acid and sucrose), Peters et al. [83] showed increased catechin absorption (from $61.0 \mathrm{pmol} \cdot \mathrm{h} / \mathrm{L}$ plasma to $181.8 \mathrm{pmol} \cdot \mathrm{h} / \mathrm{L}$ plasma) using a digestion/Caco-2 cell model. Henning et al. [84] showed increased bioavailability of GT flavonoids in healthy humans when supplemented as a capsule. In yet another study, Chow et al. [85] determined the oral bioavailability of GT catechins using human volunteers randomly assigned to different dose groups and administered a catechin supplement in capsule form with or without a breakfast. Analyses of tea catechin levels in plasma and urine showed that bioavailability was greater under fasting conditions.

GT phenols (either free, conjugated or bound) bioavailability is thus dependent upon the food vehicle (beverage or extract) or upon other foods consumed [86]. However, there also remains a critical lack of information on the interactions of GT catechins in the complex matrix in terms of their physicochemical properties [86]. Additionally, GT phenols, particularly the catechins, readily undergo biotransformation via methylation, glucuronidation, sulfation, and ring fission [87], which can affect their health benefiting properties, their site of absorption and multiple host related factors (e.g., gender, age, genetics, etc.) [88]. For more information on the bioavailability-biotransformation of phenolic based compounds, including the tea constituents, and their relationship to health, the reader is referred to other comprehensive reviews [36,86-88].

\section{Conclusions}

Evidence supporting the health benefits of GT intake, with an emphasis on the catechins, has been accumulating at an unprecedented rate over the past decade, including its ability to prevent or remediate inflammation, atherosclerosis, cancer, obesity and diabetes. The mechanisms by which GT may exert their effects have also been studied using different experimental designs and approaches. For example, it is widely agreed that phenols protect against cellular oxidative stress albeit no longer as free radical scavengers or chelators of redox metals but rather as cell signaling agents of endogenous responses. However, most GT antioxidative related research has been completed in vitro. Adding to the uncertainty of where and when GT polyphenols accumulate in or pass through the body, it is questionable that the same antioxidant effect in vitro will be similar to in vivo results. Moreover, in vivo studies are difficult if not impossible due to the current lack of methods to reliably measure ROS levels. By contrast, other studies have shown the GT pro-oxidant activity promotes endogenous antioxidant systems and thus increases antioxidant enzymes expression. Given that more evidence is available on the ability of GT polyphenols to modulate gene expression and cell signaling via animal and human studies, this mechanism may be more important in terms of preventing cancer, metabolic disorders, etc. However, more questions need to be answered: Where do GT polyphenols go? Do they stay, and for how long? How do other food matrices (such as caffeine, proteins, carbohydrates) affect the health promoting properties of GT? The choice of cell or animal models and how they relate to humans, dosages, introduction of other dietary agents and the analytical approach used should be carefully considered. Extensive meta-analysis of the existing data may aid in answering these 
questions. Moreover, the effect of GT on the GI microbiome and vice versa cannot be ignored in the context of their seemingly symbiotic relationship. Lastly, GT catechins have received the major focus of study while other polyphenols have been largely neglected. However, as the emphasis of understanding synergisms among nutraceuticals is growing, it is expected that more studies will focus on the possible roles that GT polyphenols play in concert to protect against specific cellular stresses or diseases. Nonetheless, the current studies suggest that the GT agricultural base will continue to shift from one that produces a highly popular beverage to one that also includes GT as a potent health promoting food.

\section{References}

1. Khokhar, S.; Magnusdottir, S.G.M. Total phenol, catechin, and caffeine contents of teas commonly consumed in the United Kingdom. J. Agric. Food Chem. 2002, 50, 565-570.

2. Moxham, R. Tea: Addiction, Exploitation, and Empire; Carroll \& Graf Publishers: New York, NY, USA, 2003.

3. Pettigrew, J. The Tea Companion: A Connoisseur's Guide, 1st ed.; Running Press Book Publishers: Philadelphia, PA, USA, 2004.

4. Li, X. Study on the Competitiveness of Chinese Tea in the Global Market. Master's Thesis, Nanjing Agricultural University, Nanjing, China, 2004.

5. FAO Web site. Available online: http://faostat3.fao.org/home/index.html (accessed on 18 September 2012).

6. Singh, B.N.; Shankar, S.; Srivastava, R.K. Green tea catechin, epigallocatechin-3-gallate (EGCG): Mechanisms, perspectives and clinical applications. Biochem. Pharmacol. 2011, 82, 1807-1821.

7. Butt, M.S.; Sultan, M.T. Green tea: Nature's defense against malignancies. Crit. Rev. Food Sci. Nutr. 2009, 49, 463-473.

8. Cabrera, C.; Artacho, R.; Giménez, R. Beneficial effects of green tea-A review. J. Am. Coll. Nutr. 2006, 25, 79-99.

9. Balentine, D.A.; Wiseman, S.A.; Bouwens, L.C.M. The chemistry of tea flavonoids. Crit. Rev. Food Sci. Nutr. 1997, 37, 693-704.

10. Lin, L.Z.; Chen, P.; Harnly, J.M. New phenolic components and chromatographic profiles of green and fermented teas. J. Agric. Food Chem. 2008, 56, 8130-8140.

11. Hatanaka, A. The biogeneration of green odour by green leaves. Phytochemistry 1993, 34, 1201-1218.

12. Wang, Y.; Wei, X.; Jin, Z. Structure analysis of a neutral polysaccharide isolated from green tea. Food Res. Int. 2009, 42, 739-745.

13. Chen, H.; Zhang, M.; Qu, Z.; Xie, B. Antioxidant activities of different fractions of polysaccharide conjugates from green tea (Camellia sinensis). Food Chem. 2007, 106, 559-563.

14. Circu, M.L.; Aw, T.Y. Reactive oxygen species, cellular redox systems, and apoptosis. Free Radic. Biol. Med. 2010, 48, 749-762.

15. Kowaltowski, A.J.; Souza-Pinto, N.C.; Castilho, R.F.; Vercesi, A.E. Mitochondria and reactive oxygen species. Free Radic. Biol. Med. 2009, 47, 333-343. 
16. Schroeder, E.K.; Kelsey, N.A.; Doyle, J.; Breed, E.; Bouchard, R.J.; Loucks, F.A.; Linseman, D.A. Green tea epigallocatechin 3-gallate accumulates in mitochondria and displays a selective antiapoptotic effect against inducers of mitochondrial oxidative stress in neurons. Antioxid. Redox Signal. 2009, 11, 469-480.

17. Guo, S.; Yan, J.; Yang, T.; Yang, X.; Bezard, E.; Zhao, B. Protective effects of green tea polyphenols in the 6-OHDA rat model of Parkinson's Disease through inhibition of ROS-NO pathway. Biol. Psychiatry 2007, 62, 1353-1362.

18. Quesada, I.M.; Bustos, M.; Blay, M.; Pujadas, J.; Ardèvol, A.; Salvadó, M.J.; Bladé, C.; Arola, L.; Fernández-Larrea, J. Dietary catechins and procyanidins modulate zinc homeostasis in human HepG2 cells. J. Nutr. Biochem. 2011, 22, 153-163.

19. Wei, H.; Meng, Z. Protective effects of epigallocatechin-3-gallate against lead-induced oxidative damage. Hum. Exp. Toxicol. 2010, 30, 1521-1528.

20. Lambert, J.D.; Elias, R.J. The antioxidant and pro-oxidant activities of green tea polyphenols: A role in cancer prevention. Arch. Biochem. Biophys. 2010, 501, 65-72.

21. Maeta, K.; Nomura, W.; Takatsume, Y.; Izawa, S.; Inoue, Y. Green tea polyphenols function as prooxidants to activate oxidative-stress-responsive transcription factors in yeasts. Appl. Environ. Microbiol. 2007, 73, 572-580.

22. Elbling, L.; Herbacek, I.; Weiss, R.-M.; Jantschitsch, C.; Micksche, M.; Gerner, C.; Pangratz, H.; Berger, W. Hydrogen peroxide mediates EGCG-induced antioxidant protection in human keratinocytes. Free Radic. Biol. Med. 2010, 49, 1444-1452.

23. Lin, W.; Karin, M. A cytokine-mediated link between innate immunity, inflammation, and cancer. J. Clin. Investig. 2007, 117, 1175-1183.

24. Lumeng, C.N.; Saltiel, A.R. Inflammatory links between obesity and metabolic disease. J. Clin. Investig. 2011, 121, 2111-2117.

25. Smith, G.R.; Missailidis, S. Cancer, inflammation and the AT1 and AT2 receptors. J. Inflamm. 2004, 1, 1-12.

26. Dona, M.; Dell'Aica, L.; Calabrese, F.; Benelli, R.; Morini, M.; Albini, A.; Garbisa, S. Neutrophil restraint by green tea: Inhibition of inflammation, associated angiogenesis, and pulmonary fibrosis. J. Immunol. 2003, 170, 4335-4341.

27. Shen, C.-L.; Samathanam, C.; Tatum, O.L.; Graham, S.; Tubb, C.; Cao, J.J.; Dunn, D.M.; Wang, J.-S. Green tea polyphenols avert chronic inflammation-induced myocardial fibrosis of female rats. Inflamm. Res. 2011, 60, 665-672.

28. Askenasya, N.; Kaminitza, A.; Yarkoni, S. Mechanisms of T regulatory cell function. Autoimmun. Rev. 2008, 7, 370-375.

29. Wong, C.P.; Nguyena, L.P.; Nohb, S.K.; Braya, T.B.; Brunob, R.S.; Ho, E. Induction of regulatory $\mathrm{T}$ cells by green tea polyphenol EGCG. Immunol. Lett. 2011, 139, 7-13.

30. Tsai, P.-Y.; Ka, S.-M.; Chang, J.-M.; Chen, H.-C.; Shui, H.-A.; Li, C.-Y.; Hua, K.-F.; Chang, W.-L.; Huang, J.-J.; Yang, S.-S.; et al. Epigallocatechin-3-gallate prevents lupus nephritis development in mice via enhancing the Nrf2 antioxidant pathway and inhibiting NLRP3 inflammasome activation. Free Radic. Biol. Med. 2011, 51, 744-754. 
31. Wu, D.; Guo, Z.; Ren, Z.; Guo, W.; Meydani, S.N. Green tea EGCG suppresses T cell proliferation through impairment of IL-2/IL-2 receptor signaling. Free Radic. Biol. Med. 2009, 47, 636-643.

32. Ranjith-Kumar, C.T.; Lai, Y.; Sarisky, R.T.; Kao, C.C. Green tea catechin, epigallocatechin gallate, suppresses signaling by the dsRNA innate immune receptor RIG-I. PLoS One 2010, $5, \mathrm{e} 12878$.

33. Noh, S.U.; Park, Y.M. The effect of green tea polyphenols on macrophage migration inhibitory factor-associated steroid resistance. Br. Assoc. Dermatol. 2012, 166, 653-657.

34. Ripley, B.J.M.; Fujimoto, M.; Serada, S.; Ohkawara, T.; Nishikawa, T.; Terabe, F.; Naka, T. Green tea polyphenol epigallocatechin gallate inhibits cell signaling by inducing SOCS1 gene expression. Int. Immunol. 2010, 22, 359-366.

35. Deka, A.; Vita, J.A. Tea cardiovascular disease. Pharmacol. Res. 2012, 64, 136-145.

36. Del Rio, D.; Rodriguez-Mateos, A.; Spencer, J.P.E.; Tognolini, M.; Borges, G.; Crozier, A. Dietary polyphenolics in human health: Structures, bioavailability, and evidence of protective effects against chronic diseases. Antioxid. Redox Signal. 2012, doi:10.1089/ars.2012.4581.

37. Qin, B.; Polansky, M.M.; Harry, D.; Anderson, R.A. Green tea polyphenols improve cardiac muscle mRNA and protein levels of signal pathways related to insulin and lipid metabolism and inflammation in insulin resistant rats. Mol. Nutr. Food Res. 2010, 54, S14-S23.

38. Lorenz, M.; Urban, J.; Engelhardt, U.; Baumann, G.; Stangl, K.; Stangl, V. Green and black tea are equally potent stimuli of NO production and vasodilation: New insights into tea ingredients involved. Basic Res. Cardiol. 2009, 104, 100-110.

39. El Bedoui, J.; Oak, M.H.; Anglard, P.; Schini-Kerth, V.B. Catechins prevent vascular smooth muscle cell invasion by inhibiting MT1-MMP activity and MMP-2 expression. Cardiovasc. Res. 2005, 67, 317-325.

40. Bursill, C.A.; Roach, P.D. Modulation of cholesterol metabolism by the green tea polyphenol (-)-epigallocatechin gallate in cultured human liver (HepG2) cells. J. Agric. Food Chem. 2006, 54, $1621-1626$.

41. Bursill, C.A.; Abbey, M.; Roach, P.D. A green tea extract lowers plasma cholesterol by inhibiting cholesterol synthesis and upregulating the LDL receptor in the cholesterol-fed rabbit. Atherosclerosis 2007, 193, 86-93.

42. Alexopoulos, N.; Vlachopoulos, C.; Aznaouridis, K.; Baou, K.; Vasiliadou, C.; Pietri, P.; Xaplanteris, P.; Stefanadi, E.; Stefanadis, C. The acute effect of green tea consumption on endothelial function in healthy individuals. Eur. J. Cardiovasc. Prev. Rehabil. 2008, 15, 300-305.

43. Zheng, X.-X.; Xu, Y.-L.; Li, H.-S.; Liu, X.-X.; Hui, J.; Huang, X.-H. Green tea intake lowers fasting serum total and LDL cholesterol in adults: A meta-analysis of 14 randomized controlled trials. Am. J. Clin. Nutr. 2011, 94, 601-610.

44. Sae-Tan, S.; Grove, K.A.; Lambert, J.D. Weight control and prevention of metabolic syndrome by green tea. Pharmacol. Res. 2012, 64, 146-154.

45. Bose, M.; Lambert, J.D.; Ju, J.; Reuhl, K.R.; Shapses, S.A.; Yang, C.S. The major green tea polyphenol, (-)-Epigallocatechin-3-Gallate, inhibits obesity, metabolic syndrome, and fatty liver disease in high-fat-fed mice. J. Nutr. 2008, 138, 1677-1683. 
46. Sae-Tan, S.; Grove, K.A.; Kennettb, M.J.; Lambert, J.D. (-)-Epigallocatechin-3-gallate increases the expression of genes related to fat oxidation in the skeletal muscle of high fat-fed mice. Food Funct. 2011, 2, 111-116.

47. Lee, M.-S.; Kim, C.-T.; Kim, I.-H.; Kim, Y. Inhibitory effects of green tea catechin on the lipid accumulation in 3T3-L1 adipocytes. Phytother. Res. 2009, 23, 1088-1091.

48. Richard, D.; Kefi, K.; Barbe, U.; Poli, A.; Bausero, P.; Visioli, F. Weight and plasma lipid control by decaffeinated green tea. Pharmocol. Res. 2009, 59, 351-354.

49. Cao, H.; Hininger-Favier, I.; Kelly, M.A.; Benaraba, R.; Dawson, H. D.; Coves, S.; Roussel, A.M.; Anderson, R.A. Green tea polyphenol extract regulates the expression of genes involved in glucose uptake and insulin signaling in rats fed a high fructose diet. J. Agric. Food Chem. 2007, $55,6372-6378$.

50. Hininger-Favier, I.; Benaraba, R.; Coves, S.; Anderson, R.A.; Roussel, A.M. Green tea extract decreases oxidative stress and improves insulin sensitivity in an animal model of insulin resistance, the fructose-fed rat. J. Am. Coll. Nutr. 2009, 28, 355-361.

51. Ma, J.; Li, Z.; Xing, S.; Ho, W.T.; Fu, X.; Zhao, Z.J. Tea contains potent inhibitors of tyrosine phosphatase PTP1B. Biochem. Biophys. Res. Commun. 2011, 407, 98-102.

52. Oba, S.; Nagata, C.; Nakamura, K.; Fujii, K.; Kawachi, T.; Takatsuka, N.; Shimizu, H. Consumption of coffee, green tea, oolong tea, black tea, chocolate snacks and the caffeine content in relation to risk of diabetes in Japanese men and women. Br. J. Nutr. 2010, 103, 453-459.

53. Hsu, C.-H.; Tsai, T.-H.; Kao, Y.-H.; Hwang, K.-C.; Tseng, T.-Y.; Chou, P. Effect of green tea extract on obese women: A randomized, double-blind, placebo-controlled clinical trial. Clin. Nutr. 2008, 27, 363-370.

54. Kuriyama, S.; Shimazu, T.; Ohmori, K.; Kikuchi, N.; Nakaya, N.; Nishino, Y.; Tsubono, Y.; Tsuji, I. Green tea consumption and mortality due to cardiovascular disease, cancer, and all causes in Japan: The Ohsaki study. J. Am. Med. Assoc. 2006, 296, 1255-1265.

55. Basu, A.; Sanchez, K.; Leyva, M.J.; Wu, M.; Betts, N.M.; Aston, C.E.; Lyons, T.J. Green tea supplementation affects body weight, lipids, and lipid peroxidation in obese subjects with metabolic syndrome. J. Am. Coll. Nutr. 2010, 29, 31-40.

56. Khan, N.; Mukhtar, H. Multi-targeted therapy of cancer by green tea polyphenols. Cancer Lett. 2008, 269, 269-280.

57. Ohga, N.; Hida, K.; Hida, Y.; Muraki, C.; Tsuchiya, K.; Matsuda, K.; Ohiro, Y.; Totsuka, Y.; Shindoh, M. Inhibitory effects of epigallocatechin-3 gallate, a polyphenol in green tea, on tumor-associated endothelial cells and endothelial progenitor cells. Cancer Sci. 2009, 100, 1963-1970.

58. Kato, K.; Long, N.K.; Makita, H.; Toida, M.; Yamashita, T.; Hatakeyama, D.; Hara, A.; Mori, H.; Shibata, T. Effects of green tea polyphenol on methylation status of RECK gene and cancer cell invasion in oral squamous cell carcinoma cells. Br. J. Cancer 2008, 99, 647-654.

59. Siddiqui, I.A.; Asim, M.; Hafeez, B.B.; Adhami, V.M.; Tarapore, R.S.; Mukhtar, H. Green tea polyphenol EGCG blunts androgen receptor function in prostate cancer. FASEB J. 2011, 25, 1198-1207. 
60. Lee, Y.H.; Kwak, J.; Choi, H.K.; Choi, K.C.; Kim, S.; Lee, J.; Jun, W.; Park, H.J.; Yoon, H.G. EGCG suppresses prostate cancer cell growth modulating acetylation of androgen receptor by anti-histone acetyltransferase activity. Int. J. Mol. Med. 2012, doi:10.3892/ijmm.2012.966.

61. Yuasa, Y.; Nagasaki, H.; Akiyama, Y.; Hashimoto, Y.; Takizawa, T.; Kojima, K.; Nakachi, K. DNA methylation status is inversely correlated with green tea intake and physical activity in gastric cancer patients. Int. J. Cancer 2009, 124, 2677-2682.

62. Thangapazham, R.L.; Singh, A.K.; Sharma, A.; Warren, J.; Gaddipati, J.P.; Maheshwari, R.K. Green tea polyphenols and its constituent epigallocatechin gallate inhibits proliferation of human breast cancer cells in vitro and in vivo. Cancer Lett. 2007, 245, 232-241.

63. Henning, S.M.; Wang, P.; Said, J.; Magyar, C.; Castor, B.; Doan, N.; Tosity, C.; Moro, A.; Gao, K.; Li, L.; et al. Polyphenols in brewed green tea inhibit prostate tumor xenograft growth by localizing to the tumor and decreasing oxidative stress and angiogenesis. J. Nutr. Biochem. 2012, $23,1537-1542$.

64. Bettuzzi, S.; Brausi, M.; Rizzi, F.; Castagnetti, G.; Peracchia, G.; Corti, A. Chemoprevention of human prostate cancer by oral administration of green tea catechins in volunteers with high-grade prostate intraepithelial neoplasia: A preliminary report from a one-year proof-of-principle study. Cancer Res. 2006, 66, 1234-1240.

65. Yang, C.S.; Wang, H.; Li, G.X.; Yang, Z.; Guan, F.; Jin, H. Cancer prevention by tea: Evidence from laboratory studies. Pharmacol. Res. 2012, 64, 113-122.

66. Yuan, J.-M.; Sun, C.; Butler, L.M. Tea and cancer prevention: Epidemiological studies. Pharmacol. Res. 2012, 64, 123-135.

67. Chow, H.-H.S.; Hakim, I.A. Pharmacokinetic and chemoprevention studies on tea in humans. Pharmacol. Res. 2012, 64, 105-112.

68. Flint, H.J.; Duncan, S.H.; Scott, K.P.; Louis, P. Interactions and competition within the microbial community of the human colon: Links between diet and health. Environ. Microbiol. 2007, 9, 1101-1111.

69. Cani, P.D.; Possemiers, S.; van de Wiele, T.; Guiot, Y.; Everard, A.; Rottier, O.; Geurts, L.; Naslain, D.; Neyrinck, A.; Lambert, D.M.; et al. Changes in gut microbiota control inflammation in obese mice through mechanism involving GLP-2-driven improvement of gut permeability. Gut 2009, 58, 1091-1103.

70. Corr, S.C.; Li, Y.; Riedel, C.U.; O’Toole, P.W.; Hill, C.; Gahan, C.G.M. Bacteriocin production as a mechanism for the anti-infective activity of Lactobacillus salivarius UCC118. Proc. Natl. Acad. Sci. USA 2007, 104, 7617-7621.

71. Lee, Y.K.; Menezes, J.S.; Umesaki, Y.; Mazmanian, S.K. Proinflammatory T-cell responses to gut microbiota promote experimental autoimmune encephalomyelitis. Proc. Natl. Acad. Sci. USA 2011, 108, 4615-4622.

72. Dunne, C.; Murphy, L.; Flynn, S.; O’Mahony, L.; O’Halloran, S.; Feeney, M.; Morrissey, D.; Thornton, G.; Fitzgerald, G.; Daly, C.; et al. Probiotics: from myth to reality. Demonstration of functionality in animal models of disease and in human clinical trials. Antonie van Leeuwenhoek. 1999, 76, 279-292. 
73. Crittenden, R.; Playne, M.J. Modifying the human intestinal microbiota with prebiotics. In Gastrointestinal Microbiology; Ouwehand, A.C., Vaughan, E.E., Eds.; Taylor \& Francis Inc.: New York, NY, USA, 2006; pp. 285-314.

74. Khoruts, A.; Dicksved, J.; Jansson, J.K.; Sadowsky, M.J. Changes in the composition of the human fecal microbiome after bacteriotherapy for recurrent Clostridium difficile-associated diarrhea. J. Clin. Gastroenterol. 2010, 44, 354-360.

75. Lee, H.C.; Jenner, A.M.; Low, C.S.; Lee, Y.K. Effect of tea phenolics and their aromatic fecal bacterial metabolites on intestinal microbiota. Res. Microbiol. 2006, 157, 876-884.

76. Su, P.; Henriksson, A.; Nilsson, C.; Mitchell, H. Synergistic effect of green tea extract and probiotics on the pathogenic bacteria, Staphylococcus aureus and Streptococcus pyogenes. World J. Microbiol. Biotechnol. 2008, 24, 1837-1841.

77. Sutherland, J.; Miles, M.; Hedderley, D.; Li, J.; Devoy, S.; Sutton, K.; Lauren, D. In vitro effects of food extracts on selected probiotic and pathogenic bacteria. Int. J. Food Sci. Nutr. 2009, 60, 717-727.

78. Molan, A.L.; Flanagan, J.; Wei, W.; Moughan, P.J. Selenium-containing green tea has higher antioxidant and prebiotic activities than regular green tea. Food Chem. 2009, 114, 829-835.

79. Green, R.J.; Murphy, A.S.; Schulz, B.; Watkins, B.A.; Ferruzzi, M.G. Common tea formulations modulate in vitro digestive recovery of green tea catechins. Mol. Nutr. Food Res. 2007, 51, $1152-1162$.

80. Stalmach, A.; Troufflard, S.; Serafini, M.; Crozier, A. Absorption, metabolism and excretion of Choladi green tea flavan-3-ols by humans. Mol. Nutr. Food Res. 2009, 53, S44-S53.

81. Roowi, S.; Stalmach, A.; Mullen, W.; Lean, W.E.J.; Edwards, C.A.; Crozier, A. Green tea flavan-3-ols: Colonic degradation and urinary excretion of catabolites by humans. J. Agric. Food Chem. 2010, 58, 1296-1304.

82. Calani, L.; Del Rio, D.; Luisa Callegari, M.; Morelli, L.; Brighenti, F. Updated bioavailability and $48 \mathrm{~h}$ excretion profile of flavan-3-ols from green tea in humans. Int. J. Food Sci. Nutr. 2012, 63, 513-521.

83. Peters, C.M.; Green, R.J.; Janle, E.M.; Ferruzzi, M.G. Formulation with ascorbic acid and sucrose modulates catechin bioavailability from green tea. Food Res. Int. 2010, 43, 95-102.

84. Henning, S.M.; Niu, Y.; Lee, N.H.; Thames, G.D.; Minutti, R.R.; Wang, H.; Go, V.L.W.; Heber, D. Bioavailability and antioxidant activity of tea flavanols after consumption of green tea, black tea, or a green tea extract supplement. Am. J. Clin. Nutr. 2004, 80, 1558-1564.

85. Chow, H.-H.S.; Hakim, I.A.; Vining, D.R.; Crowell, J.A.; Ranger-Moore, J.; Chew, W.M.; Celaya, C.A.; Rodney, S.R.; Hara, Y.; Alberts, D.A. Effects of dosing condition on the oral bioavailability of green tea catechins after single-dose administration of polyphenon $\mathrm{E}$ in healthy individuals. Clin. Cancer Res. 2005, 11, 4627-4633.

86. Archivio, M.D.; Filesi, C.; Rosaria, V.; Scazzocchio, B.; Masella, R. Bioavailability of the polyphenols: Status and controversies. Int. J. Mol. Sci. 2010, 11, 1321-1342.

87. Sang, S.; Lambert, J.D.; Ho, C.-T.; Yang, C.S. The chemistry and biotransformation of tea constituents. Pharmacol. Res. 2011, 64, 87-99. 
88. Hollman, P.C.H. Absorption, bioavailability and metabolism of flavonoids. Pharm. Biol. 2004, $42,74-83$.

(C) 2012 by the authors; licensee MDPI, Basel, Switzerland. This article is an open access article distributed under the terms and conditions of the Creative Commons Attribution license (http://creativecommons.org/licenses/by/3.0/). 